\title{
Ergonomics and the inclusion of people with disabilities in a Brazilian workplace
}

\author{
Francisco de Paula Nunes Sobrinho ${ }^{1}$ and Uilielma Ferreira de Lucena \\ Rio de Janeiro State University, Rua São Francisco Xavier 524 - bl. A / s. 12017 \\ 20.550-900 - Maracanã - Rio de Janeiro, RJ - Brasil
}

\begin{abstract}
The customization of a secretary workstation at a drama school was the objective of this case study. The investigation involved a 25-year-old illiterate woman with intellectual disabilities and low vision that had been been attending, for over 12 years, a state school for people with disabilities. The customization process, operationalized after a diagnosis was made, focused on environmental rearrangements, with the purpose of meeting the physical and social demands of the workstation. The results of this research are configured in an ergonomic analysis of work associated with an inventory of social skills, applied to people living directly with the participant. Preliminary evaluations indicated the degree of adjustment of labor demands to the personal characteristics of the participant in the customized job.
\end{abstract}

Keywords: people with disabilities, customization job, social skills.

\section{Introduction}

The objective of this study is to customize a workstation located on the premises of an office located at a public school theater. The research involved a 25-year-old illiterate woman with intellectual disabilities that had low vision and had been attending, for over 12 years, a state school for people with disabilities. As a case study, this investigation provides a detailed description of the characteristics of a single participant. The proposal focuses on the relationships established between this individual and the demands of a job. In terms of case study, the individual may be considered to be one person, but also an environment, business organization, school or neighborhood, according to Cozby [10].

The literature on this research topic indicates that the concept of customization of work is still unclear and lacks objective definition; there is no consensus among experts in the field as assigned by Luecking [2]. The popular use of the word customization refers to the idea of adapting professional environments, in order to make them compatible with the values, be- liefs, immediate needs, interests, desires and preferences of the job occupant. In this way, workers may, personally and in a satisfactory manner, execute their duties (prescribed work), in the way they consider most convenient (real job), preserving their health, safety and quality of life, according to Nunes Sobrinho [3]; Oliveira [4]. In short, the customization process involves transforming the work environment to meet the occupational demands, which involves the systematic humanization of the work itself as pointed out by Nunes Sobrinho [4].

In this study, the concept of customization work approaches the concept of Human Factors and Ergonomics and its domains: Organizational Ergonomics, Cognitive Ergonomics and Physical Ergonomics ABERGO [5] and IEA [6]. It is the duty of the ergonomist to conduct corrective or preventive actions in order to avoid violations or transgressions of rules and laws present in relations established in complex work systems. The essence of the ergonomic proposal is, therefore, to project and resize workstations, considering the limitations and potentials of the human operator in the diversity of contexts and most

${ }^{1}$ Corresponding author: fnunessobrinho@yahoo.com.br 
extreme working conditions. The task of the ergonomist is to transform the work, adapting it to the man who performs it, according to Guerin et al. [7].

For this study, we conducted a preliminary analysis of the literature that addresses the process of adapting work to people with disabilities, considering the transition from school to work and the development of social skills as a topic of interest in the employability of this group of people in the competitive market, according to Bambara, Koeger \& Bartholomew [8]; Luecking [2]; Nunes Sobrinho [9]; Nunes Sobrinho [10]; Del Prette \& Del Prette [11]; Test \& Mazotti [12]; Giangreco [14].

Teaching social skills to people with disabilities in domestic and community settings has been vastly debated in the literature. Since the 1970s studies have focused on teaching functional skills to this population. Bambara, Koeger \& Bartholomew [8] describe how teachers can encourage students to acquire skills to use in their homes and communities in general, specifically in the workplace. In this regard, when it comes to customizing jobs, decisions about what and how to teach need to be taken in consultation with students and their families, always honoring their values, preferences and expectations for the future. Instructional programs offered in the transition from school to work should be directed to the acquisition of basic skills of autonomy and self-determination. This is viable through the process of learning how to make choices, always respecting the individual preferences.

During the transition from school to work, teaching strategies are combined with experiences in formal and informal education. This encourages the use of skills of social interaction among peers, who may become future colleagues. There is still much to be done in the field of transition from school to employment. Test and Mazzotti [12], in a book chapter entitled The transition from school to work, highlight the importance of bringing up specific themes related to work for people with disabilities. This may prevent future problems in the passage to adulthood. Part of this chapter is devoted to the historical development of the transition process with reference to the 1960 's, a period when programs such as work / study sites, as part of the academic, professional and social curriculum were installed. These programs were initially targeted for teaching skills for students with mild intellectual disabilities to live in communities. In the 1970 `s the trend was "career education" followed by the period 1980-1990, marked by rapid expansion of transition services offered in the USA. In this context, it is important to highlight the low rates of em- ployment for students with severe disabilities in our environment, even when these individuals achieve higher levels of education.

Test \& Mazotti [12] describe, in details, the different types of procedures used in the transition process of school to work. This involves from the most segregated to those who favor the rapid determination of students. The research conducted by Luecking [2] is crucial for bringing about a paradigm shift regarding the employability of people with disabilities in our context. The author considers that employment is one of the contributing factors to improve quality of life for people with disabilities. This means that the successful experiences of work must be an integral part for transition preparation. In his book The way to work: how to facilitate work experience for young people in transition, the author discusses topics of importance in the transition to work. Its purpose is to teach specialists strategies for guiding their students with disabilities find employment in a competitive market. The book also offers subsidies in the training of professionals and specialists who deal directly with the process of transition to work. Among the topics covered are the work experience, educational procedures, and ways of finding and recruiting partnerships with employers and employment agencies.

\section{Method}

\subsection{Ethical issues}

Ethical requirements were met in accordance with Resolution 196/96 of the National Health Council, with regard to the Guidelines and Norms Regulating Research Involving Human Subjects. The project was then submitted for review and approval. A letter explaining the objectives and procedures of the research were presented to the participants prior to the conduction of the interviews and the application of the scales for assessing social skills. A Statement of Agreement explaining the objectives, procedures and voluntary nature of participation (free of any financial or personal loss) was presented to each participant.

\subsection{Participant}

A 25-year-old illiterate woman with intellectual disabilities and low vision was the primary participant of this study. Her development was equivalent to a $5^{\text {th }}$ grader and she had been attending a state school for people with disabilities for over 12 years. 
Other participants were people in direct contact with her. These included her mother, her caretaker, the classroom teachers, one of the researchers, other educators (caregivers) and classmates.

\subsection{Setting}

Data collection was performed at a workstation located at an office of a drama school and a special education school. Both settings were within a public school system in the western area of the city of Rio de Janeiro.

\subsection{Social Skills}

In this study, the concept of social competence refers to the effective use of the repertoire of social skills that result in positive interactions with others. (Del Prette \& Del Prette 2007).

In the case of children and adolescents, social skills often emphasized and valued in international studies can be grouped into five sets, as indicated Caldarelli \& Merrell (1997):

1) relationship with peers - composed of skills that demonstrate positive attitudes with colleagues such as: greeting, compliment, offer help or assistance, or invite to games or other types of interactions;

2) self-control - made up of skills that demonstrate emotional adjustment such as mood control, follow rules, respect boundaries, negotiating, handling criticism and tolerating frustrations;

3) social academic skills - involve the ability to work independently and productively in the classroom, such as engaging in the task, doing it independently and following instructions;

4) adjustment - composed of cooperative skills, such as following rules and behaving in accordance with expectations, proper use of free time, sharing things and attending to requests;

5) assertion - made up of expressive skills such as initiating conversations, accepting compliments, making invitations.

\subsection{Social Skills Scales}

A social skills assessment was conducted with the primary participant. The instruments included two scales with similar language, considering the characteristics of the respondents: the main participant (self-assessment, with the help of the researcher), peer group, three teachers, two social educators, one of the researchers, the mother of the participant and the caretaker. The application of the scale was conducted in two stages.

\section{Ergonomic work analysis}

Ergonomic Work Analysis (EWA) is conceptualized by Nunes Sobrinho [4] as the study of interrelationships between psychological, behavioral, cognitive, psychophysical, biomechanical, social, among other characteristics of the worker and the social and physical events in complex systems. However, this author points out the unfeasibility of the ergonomist encompassing all of these interfaces, as suggested in the model of EWA. It is generally accepted the idea that the EWA will assume greater significance when data on these interrelationships derive from different research perspectives. In this sense it can involve data produced with the most or least rigorous experimental control.

In this context, the following EWA procedures were developed: interview with the coordinator, application of social skills scales in people of daily contact with the participant, identifying the demands of the job, description of typical tasks, observation and data collection on conditions of physical and social environment. Simultaneously, hypotheses were formulated for the purpose of customizing the job under study, for example, "the participant has expertise in answering phone calls to" or "contingency arrangement is necessary to customization process of the job."

\section{Results and Discussion}

A survey for the purpose of customizing the job for the 25-year-old female was concluded. The results reinforce the need for changes on the employment of persons with disabilities, also opening up perspectives for improving the process of transition from school to work. Moreover, the pattern of relationship maintained between the researcher and research participant proved relevant for the purposes of data collection. As noted, a trust was established between the participant and the researcher which facilitated the process.

An ergonomic analysis suggested a labor demand appropriate to the position of the existing work, as well as adjustments and rearrangement of the work environment related to the characteristics of the primary participant. 
Table 1

First stage of implementation of the scales of social skills of the participant.

\begin{tabular}{|l|l|}
\hline Persons & \\
\hline P1 & Caregiving: a person who provides care to the participant when the mother is absent. \\
\hline P2, P3 & $\begin{array}{c}\text { Social educator: rofessional Who oversees the activities of the participant during the hours of } \\
\text { recreation and also outside the classroom. }\end{array}$ \\
\hline P4 & Former Teacher: more than 1 year working at school. \\
\hline P5, P6 & New Teacher: less than 1 year of work at school \\
\hline
\end{tabular}

Table 1

Second stage of implementation of the scales of social skills of the participant.

\begin{tabular}{|l|l|}
\hline Persons & \\
\hline P7 & The participant \\
\hline P8 & Mother of participant \\
\hline P9 & Researcher \\
\hline
\end{tabular}

The data show the responsiveness of the target institution in welcoming people with disabilities to their workforce. Possibly, this is justified because of the positive experiences with this type of population, as revealed by the interviews conducted with the staff. In addition, the participant had previously had experience working as a receptionist in the same educational institution.

In the present study, an ergonomic work analysis was assigned to the participant, as the operational support of the workstation: a) select and sort folders of documents, b) answer phone calls, c) welcome visitors and users of the school d) direct people at various events, and assist in the distribution of meals for students; f) operate the Xerox machine g) deliver, forward, distribute and dispatch documents and correspondence by the network of schools located on campus.

Based on the behavioral characteristics of the participant, the initial labor day consisted of 2 (two) working hours per day on Tuesdays and Thursdays, at the time of 1p.m to 3 p.m., with the possibility of increase in workload. Labor time could not, however, be less than 2 hours or more than 4 hours daily. The same occurred with the working days, which were never less than 2 or more than 5 days a week. It should be noted that the work was unpaid.
An employee was assigned to oversee and coordinate the participant's activities, as she adjusted to the new routine. It is relevant to emphasize that this was not a protected job, considering that the researchers' proposal was to rearrangement the environment in order to adapt it to the demands and encourage the autonomy of participating in the competitive market. It is necessary to point out that the participant did not demonstrate mastery of skills in both reading and writing, which was relevant in the process of customizing the job.

The participant's social skills, as evaluated by the individuals that interacted with her on a regular basis, are presented in the graphs below. The opinions of teachers with less than a year of work and direct contact with the participant differ from those with more than a year of interaction. Teachers who had a closer relation with the participant stated that she stood up for herself when annoyed. On the other hand, teachers who interacted less with the participant stated that she annoyed others and liked to fight. In general, satisfactory results are revealed in the self-control domain of social skills, as shown in Figure 1.

Based on the results obtained by applying the scales of social skills, the participant demonstrated a good relationship with peers, teachers and school staff, as Figures 2, 3 and 4. 


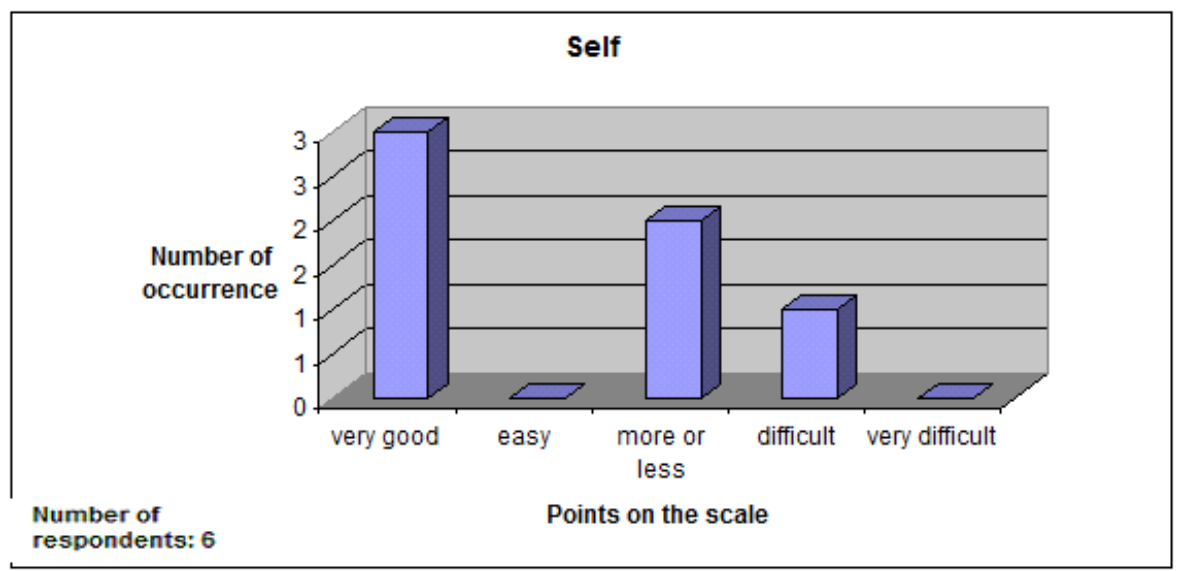

Figure 1 - The participant's self, according to respondents' conception of the scale of social skills.

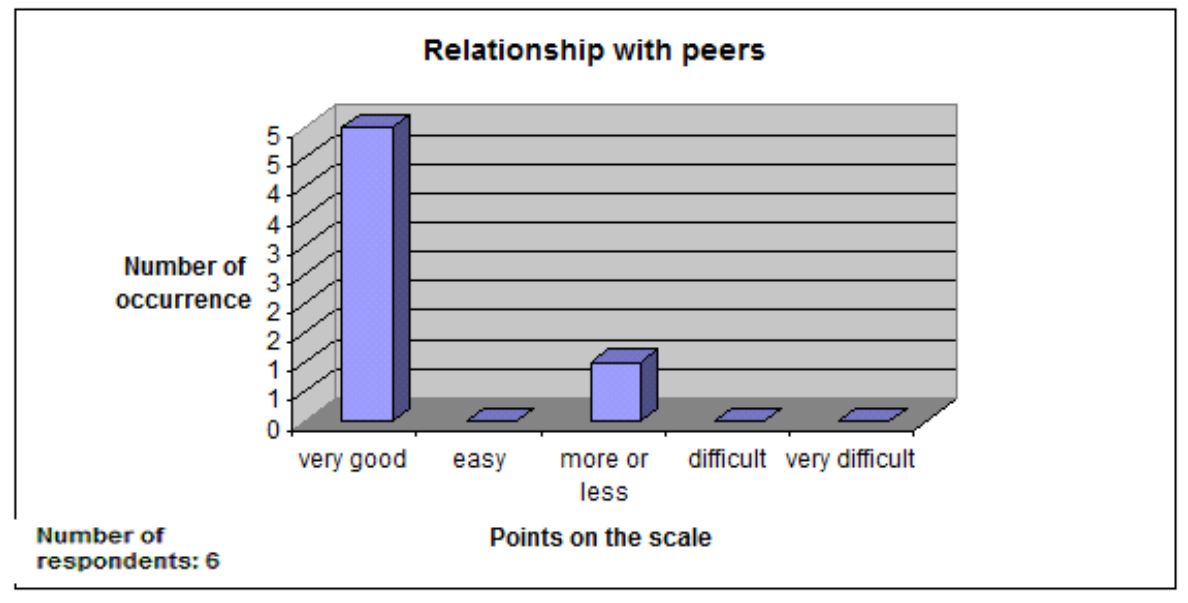

Figure 2 - Social skills of the participant's relationship with peers and superiors (teachers, educators, parents and caregiver).

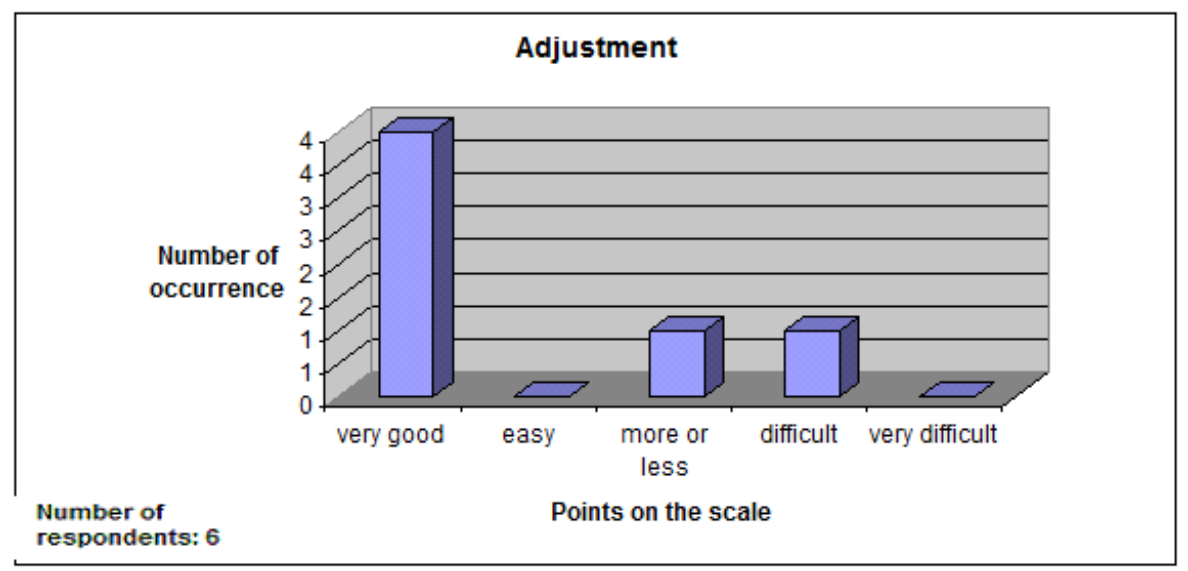

Figure 3 - The expected behavior of participating in social groups. 


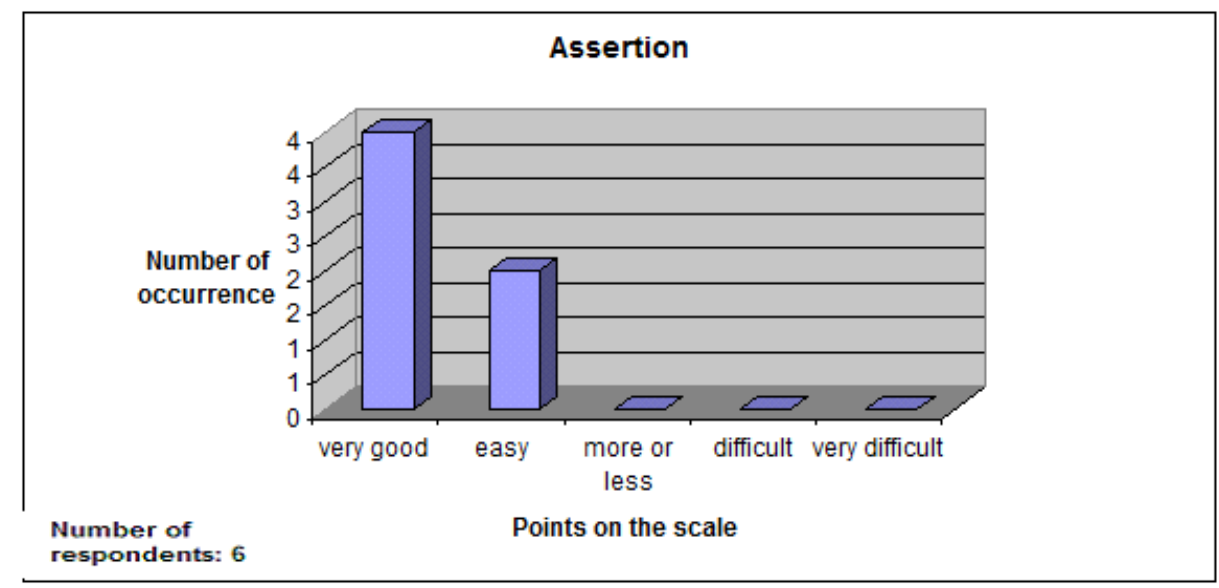

Figure 4 - The participant's relations with the general public (people outside the school).

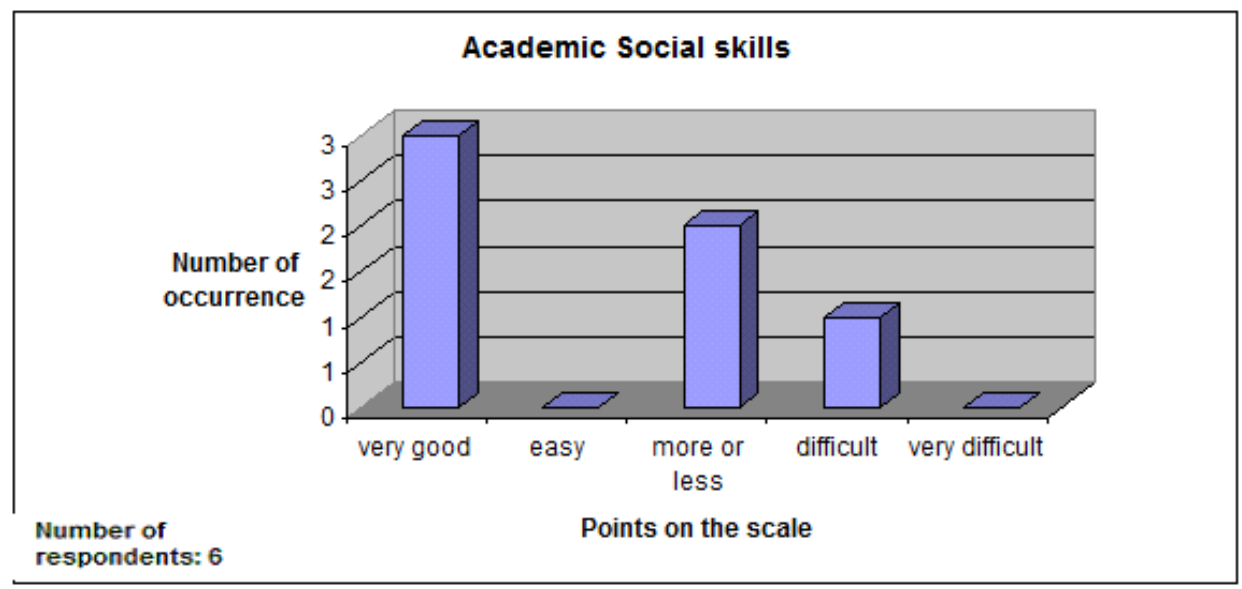

Figure 5 - Social skills related to school performance.

These results are of relevance, considering that satisfactory social skills indicate, among other factors, better Life Quality at Work. According to Del Prette $\&$ Del Prette [11], when the subject has a good relationship with peers and superiors, it means he/she does not have significant difficulties with social skills and that limitations may be caused by punctual factors, as it was observed in the present study.

One aspect to consider is that the participant has been attending the same school for over 12 years and has been in contact with her current classmates for the past two years. During an interview with the researcher, the participant reported lack of motivation since the school failed to offer new things to learn. "Everything is repetition." Possibly, the transition from school to work will facilitate the recognition that the school can teach "things" that will be applied in work situations. In fact, the participant had previous experience as a receptionist at the school, which was positive. The interview data with the mother and caregiver revealed that the job experience granted her with greater sense of responsibility, both at home and at school.

Figure 5 shows that the participant has good academic performance but lacks reading and writing skills. Being illiterate can, probably, contribute to her feeling of frustration and lack of motivation. She, does, however, recognize letters and numbers and is able to copy, although not understand what she writes.

Finally, it should be highlighted the fact that the traditional procedures of attraction (recruitment) and the selection of so-called normal people, to work, do 
not seem to fit the peculiarities and diversity, especially when it comes to people with disabilities. This occurs because of excessive inter-subject variability, which would justify the appropriateness and need for more research projects on this topic, using the case study method.

\section{References}

[1] Cozby, Paul C. Métodos de pesquisa em ciências do comportamento. São Paulo: Editora Atlas, 2003.

[2] Luecking, Richard G. The way to work: how to experiences for youth in transition. Baltimore: Paul H. Brookes, 2009.

[3] Nunes Sobrinho, Francisco P. Delineamento de pesquisa experimental intra-sujeitos. In. F. Nunes Sobrinho e M. I. Naujorks. Pesquisa em educação Especial: desafio da qualificação. Bauru, São Paulo: EDUSC Editora do Coração Sagrado, 2001, p. 69-89.

[4] Nunes Sobrinho, Francisco P. O perfil profissional do pedagogo nas instituições: análise de relatos verbais. In: F. Nunes Sobrinho \& I. Nassaralla. Pedagogia Institucional: Fatores Humanos nas organizações.. Rio de Janeiro: Zit Editora. 2004, p. 1-22.

[5] ABERGO - Associação Brasileira de Ergonomia. Disponível em: $<$ http://www.abergo.org.Br $>$. Acesso em: 2 de Jan. 2011.

[6] IEA - International Ergonomics Association. Disponível em: $<$ http: //www. Iea.cc/>. Acesso em: fev. 2011.
[7] Guérin. F. Et al. Comprender o trabalho para transformá-lo: a prática da ergonomia. São Paulo: Edgar Blücher, 2001.

[8] Bambara, L.; Koeger, F.; Bartholomew, A. Building skills for home and community. In M, Snell \& F. Brown. Instruction of students with severe disabilities.7th ed.. Boston: Pearson Education, 2011, p. 529-568.

[9] Nunes Sobrinho, Francisco P. et al. Análise experimental do comportamento na posição sentada: ergonomia do mobiliário escolar. In. B. Rangé (Org.). Psicoterapia comportamental e cognitiva. Campinas, São Paulo: Editorial Psy II.1995, p.313322.

[10] Nunes Sobrinho, F. P. An experimental analysis of the effect design on body motion, oral reading accuracy, and reading comprehension of hyperactive students. Tese em Educação Especial, para obtenção do título de Ph.D. pela Vanderbilt University, Nashville, TN, EUA. 1985.

[11] Del Prette, A; Del Prette, Z. A. P (orgs.). Habilidades sociais, desenvolvimento e aprendizagem: questões conceituais, avaliação e intervenção. Campinas, SP: Editora Alínea, 2003.

[12] Test, D. W; Mazzotti, V. L. Transitioning from School to Employment. In M. Snell \& F. Brown. Instruction of students with severe disabilities.7th ed. Boston: Pearson Education. 2011, pp. 569-61.

[13], Caldarelli, P.; Merrel, K. Common dimensions of social skillsof children and adolescents: a taxonomy of positive behaviors. School Psychology Review, 1997, 26, p. 264-278.

[14 ] Giangreco, Michael F. Educating students with severe disabilities: foundational concepts and practices. In M. Snell \& F. Brown. Instruction of Students with Severe Disabilities. 7th ed. Boston: Pearson Education, 2011, p 1- 30. 